\title{
地下すべり面推定における三次元移動軌跡法の改良 \\ Improvements on Three Dimensional Tracking Method \\ for Presumption of Underground Slide Surface
}

\author{
吉 澤 孝 和* 宮 澤圭* \\ Norikazu Yoshizawa Kei MiYazawa
}

\begin{abstract}
Some improvements on analytic procedure of "three dimensional tracking method" used for presumption of underground-slide-surface-geometry in landslide area is discussed. Compared with the previous procedure (cf. J. of JLS, Vol. 26, No. 3, 1989), main improvements are summarized as follows:

1) to debug the singular matrix appeared in normal equation derived by least-square-method,

2) to process arbitrary number of boundary-point-data mathematically, and

3) to consider positional error of the boundary-point-data and tracking-point-data.

By these improvements, the procedure became simple and rational, thus the presumption reliable. Through computer simulation, precision of the presumption affected by selection of the boundary-points and trackingpoints is studied. At the same time, influence of the positional error is examined.

Application of the improved procedure to actual landslide in Komoro district is demonstrated.

キーワード：測量，すべり面，最小二乗法
\end{abstract}

\section{1.はじめに}

三次元移動軌跡法は，本誌 (Vol. 26，No. 3，1989) で筆者が提案した，測量データを用いた地下すべり面形 状の推定法のひとつである1”。こ手法は, 地すべり地の 地表に選定した変位追跡点 (tracking-point: 地表の変位 を追跡するための測点や地表物体）の三次元移動軌跡を 用いて，地下の主すべり面の三次元形状を最小二乗法に よって推定するものであるが，最小二乗法で導かれた正 規方程式 (normal equation) が特異行列を含むところに 問題があった。これの解決法はまず，ひとつの変位追跡 点の位置ですべり面の深さを仮定して正規方程式を修正 し，この修正した正規方程式を解いて仮の曲面を求めた。 つぎに，この仮の曲面が 3 個所の地すべり境界点 (boundary-point: 地すべりの影響が及ぶ限界と見なし 得る場所に発生している龟裂や段差等）を通過するよう に修正し，これを推定すべり面とした。このような二段 階の手数を要するほか, この手法では, すべり面の深さ を仮定するひとつの変位追跡点の選び方や境界点の与え 方によって，推定されるすべり面の形状に差が生じてく ることおよび同時に選定できる境界点は 3 点のみであ る等の問題があった。本文はこのような解析上の不都合

* 信州大学工学部
を改良することを目的として次のような検討を試みたも のである。

a) 最小二乗法で得られる正規方程式に特異行列が含ま れないような解析理論を導く。

b ）任意の個数の境界点のデー夕を同時に解析に取り入 れて処理できるようにする。

c ）変位追跡点および境界点のデータに含まれる誤差の 影響を考慮した解析手法を検討する。

\section{2. 解析理論}

地すべり地において地中に発生したせん断破壊面が地 表面と交わる部分には，亀裂や段差などの变状が現われ る。それらの近傍では破壊作用が激しく，地上の諸物体 も原形を留め得ない。しかし亀裂や段差によって分断さ れた個々のブロック上に存在する地物には顕著な変形は 見られず，相互の地物の位置関係も地すべり発生前とほ ほ同一の形態を保って集団的に移動する場合が多い。こ の現象は, 地すべりの発生により地山が龟裂や段差で分 断されてブロック化したのちには，個々の移動ブロック はそれ自体に大きなひずみを生ずることなく，主すべり 面の上を移動しているものと解釈できる。これが本文の 解析手法の論拠となる基本的な概念である。

\section{1 解析上の仮定および諸条件}

(1)地下の主すべり面は連続した曲面形状となる。本稿で 
はこれを次の二次曲面方程式で表す:

$$
H=a X^{2}+b X Y+c Y^{2}+d X+e Y+f
$$

ここに $H$ は標高, $X Y$ は平面座標值である。

(2)地すべり地全体を包囲するような形態で地表に生じた 亀裂や段差は, 地下に発生した主すべり面と地表面とが 交わった現象と考える。このような亀裂や段差の発生場 所で解析用の三次元座標を与える点を地すべり境界点 （または単に境界点）と呼ぶ。この仮定により式(1)の曲面 は境界点を通ることになる。すなわち任意の地すべり境 界点 $(i)$ の座標を $(X, Y, H)_{B i}$ とすれば次式が成り立た なければならない:

$$
H_{B i}=a X_{B i}{ }^{2}+b X_{B i} Y_{B i}+c Y_{B i}{ }^{2}+d X_{B i}+e Y_{B i}+f
$$

(3)地すべり境界点で囲まれた領域内の各所に生ずる亀裂 や段差は，主すべり面の上を移動する土石物質の中に生 じた二次的な地すべりによる現象である。この二次的な すべり面をはさむ両側の土石物質（移動ブロック）が相 対的に変位する量は, 各移動ブロックが主すべり面の上 を移動する量に比べて無視できる。

(4)地すべりによって個々の移動ブロックに生ずる変形量 はブロックの移動量に比べて無視できる。

ここで(3)と(4)の仮定から，すべての移動ブロックは, 地下に形成された主すべり面の上を，固体のような状態 を保って集団的に移動することになる。したがって各移 動ブロックの地表面に設けた変位追跡点から地下の主す べり面までの深さは, 地すべりの規模に比べてブロック が比較的小さい移動量（頭部と脚部間の最大斜面距離の 1/200 以下を目安とする)を示す場合は，ほぼ一定值とみ なすことができる。いま, 任意の変位追跡点 $(j)$ の位置で のすべり面の深さを $D_{j}$, 観測時点 $(t)$ におけるこの点の 座標を $(X, Y, H)_{T j t}$ とすれば, 式(1)から次の関係が得 られる。ただしすべり面の深さ $D_{j}$ は未知量である。

$$
\begin{aligned}
H_{T j t}-D_{j} & =a X_{T j t}{ }^{2}+b X_{T j t} Y_{T j t}+c Y_{T j t}{ }^{2} \\
& +d X_{T j t}+e Y_{T j t}+f \ldots \ldots \ldots \ldots . . . . . . . .
\end{aligned}
$$

(5)地すべり地内におけるボーリング探査等のサウンディ ングによって得られた地下のすべり面の位置を探査点 (sounding point) と呼ぶ。この点も式(1)の曲面上に存在 するという条件を与えれば，ひとつの探査点 $(k)$ の座標 を $(X, Y, H)_{S k}$ とするとき次式が成立しなければならな ᄂ:

$$
\begin{aligned}
H_{S k} & =a X_{S k}^{2}+b X_{S k} Y_{S k}+c Y_{S k}^{2}+d X_{S k} \\
& +e Y_{S k}+f \cdots \ldots \ldots \ldots \ldots \ldots \ldots \ldots \ldots \ldots \ldots \ldots \ldots \ldots \ldots \ldots \ldots \ldots \ldots \ldots \ldots \ldots \ldots
\end{aligned}
$$

\section{2 最小二乗法による解析式の誘導}

変位追跡点, 地すべり境界点および探査点の座標值は いずれも測定值であるために誤差をともなう。これに加 えて上記(1)（5)の仮定や条件に起因する誤差も介入する ために，式(2)，(3)，(4)にはつぎのような残差が生ずる:

$$
\begin{aligned}
& V_{B i}=a X_{B i}{ }^{2}+b X_{B i} Y_{B i}+c Y_{B i}{ }^{2}+d X_{B i} \\
& +e Y_{B i}+f-H_{B i} \\
& V_{T j t}=a X_{T j t}^{2}+b X_{T j t} Y_{T j t}+c Y_{T j t}^{2}+d X_{T j t} \\
& +e Y_{T_{j t}}+f-H_{T_{j t}}+D_{j} \\
& V_{S k}=a X_{S k}^{2}+b X_{S k} Y_{S k}+c Y_{S k}^{2}+d X_{S k} \\
& +e Y_{S k}+f-H_{S k}
\end{aligned}
$$

ここで最小二乗法の原理を用いて，曲面方程式のパラ メータ $(a, b, c, d, e, f)$ および各変位追跡点の直下 のすべり面の深さ $\left(D_{j}\right)$ を定める。いま地すべり境界点 の総数を $p$ 個, 変位追跡点の総数を $q$ 個, 探査点の総数を $r$ 個とすれば，最小二乗法を適用するための目的関数 $\Omega$ はつぎのように表わされる:

$$
\begin{aligned}
\Omega & =\left[w_{B i} \cdot V_{B i}{ }^{2}\right]_{i=1}{ }^{p}+\left[w_{T j}\left[V_{T j t}{ }^{2}\right]_{t=1}{ }^{u}\right]_{j=1}{ }^{q} \\
& +\left[w_{S k} \cdot V_{S k}{ }^{2}\right]_{k=1}{ }^{r} \quad \ldots \ldots \ldots \ldots \ldots \ldots \ldots \ldots \ldots \ldots \ldots \ldots \ldots \ldots \ldots \ldots \ldots \ldots \ldots \ldots \ldots
\end{aligned}
$$

ここに [ ]は和の記号をあらわす。 $w_{B i}, w_{T j}, w_{S k}$ は個々 の境界点, 変位追跡点, 探査点の座標データの誤差を考 慮した場合の重みである。また変位追跡点 $(j)$ における観 測時点の総数を $(u)$ とする。

式(8)の右辺の各項の意味と扱いかたを以下に要約する。 $\left[w_{B i} \cdot V_{B i}{ }^{2}\right]_{i=1}{ }^{p}$ : 個々の地すべり境界点で生ずる残差の 二乗に重みをつけて全点 $p$ 個について合計したもの。残 差 $V_{B i}$ は個々の境界点の三次元座標を地形図等から読み 取り，これを式(5)に代入して得られる量である。重み $w_{B i}$ は現場における地すべり境界点の位置の確認に対する信 頼度と，その位置を地形図上にプロットしてデータ化す る場合の精度から定めるべきものである。

$\left[w_{T j} \cdot\left[V_{T j t}{ }^{2}\right]_{t=1}{ }^{u}\right]_{j=1}{ }^{q}:$ 変位追跡点で生ずる残差の二乗 に重みを付けて全点 $j$ 個のすべての観測時点について合 計したもの。ひとつの変位追跡点 $(j)$ に対して $(u)$ 回の観 測時点で変位追跡観測が行なわれた場合， $(u)$ 組の三次 元座標が得られる。よってこの点には $(u)$ 個の残差 $\left(V_{T j 1}, V_{T j 2}, V_{T j 3}, \cdots \cdots, V_{T j u}\right)$ が存在し, これらの平方 和を $\left[V_{T j t}{ }^{2}\right]_{t=1}{ }^{u}$ で表わす。この変位追跡点 $(j)$ の解析上の 重み $w_{T_{j}}$ は, 後述するように $(u)$ 個のデータのばらつき の程度によって算出する。

地すべり地における変位追跡点の総数は $q$ 個である。 個々の変位追跡点で生ずる残差の二乗に重みを付けてす べて寄せ集めたものを $\left[w_{T j} \cdot\left[V_{T j t}{ }^{2}\right]_{t=1}{ }^{u}\right]_{j=1}{ }^{q}$ で表わす。

なおこの解析手法においては各変位追跡点の観測時点 を統一する必要はない。個々の変位追跡点に関して任意 の観測時点で得られた三次元座標デー夕を自由に解析に 用いることができる。

$\left[w_{S k} \cdot V_{S B k}{ }^{2}\right]_{k=1}^{r}:$ 探査点で生ずる残差の二乗に重みを付 けて全点 $r$ 個について合計したもの。個々の探查点の地 表点の位置を地形図上にプロットして地表座標を読み取 り, 地表座標の標高から探査点で得られたすべり面の深 さを差し引いたものを探查境界点の座標として式(7)に用 
いる。重み $w_{S k}$ は調査現場におけるすべり面の深さの確 認の信頼度および地形図上における調査点の位置のプ ロットの精度から定める。

すべり面方程式(1)のパラメータ: $a, b, c, d, e, f お$ よび変位追跡点におけるすべりの深さ： $D_{1}, \cdots D_{j}$, $\cdots \cdots, D_{q}$ を定めるためには式(8)の目的関数に対してつぎ
の条件を与える：

$\partial \Omega / \partial a=0, \partial \Omega / \partial b=0, \partial \Omega / \partial c=0, \partial \Omega / \partial d=0$, $\partial \Omega / \partial e=0, \partial \Omega / \partial f=0, \partial \Omega / \partial D_{1}=0$,

$$
\cdot \partial \Omega / \partial D_{j}=0, \cdots \cdots \cdots, \partial \Omega / \partial D_{q}=0
$$

この条件によって導かれる $(6+q)$ 本の連立方程式はつ ぎのようにまとめられる:

\begin{tabular}{|c|c|c|c|c|c|c|c|c|c|c|c|}
\hline$\left[w X^{4}\right]$ & {$\left[w X^{3} Y\right] \quad\left[w X^{2} Y^{2}\right]$} & {$\left[w X^{3}\right]$} & {$\left[w X^{2} Y\right]$} & {$\left[w X^{2}\right]$} & {$\left[w X^{2}\right]_{T 1}$} & $\cdots$ & {$\left[w X^{2}\right]_{T_{j}}$} & $\cdots \quad\left[w X^{2}\right]_{T q}$ & $a$ & & {$\left[w X^{2} H\right]$} \\
\hline$\left[w X^{3} Y\right]$ & {$\left[w X^{2} Y^{2}\right]\left[w X Y^{3}\right]$} & {$\left[w X^{2} Y\right]$} & {$\left[w X Y^{2}\right]$} & {$[w X Y]$} & {$[w X Y]_{T 1}$} & ... & {$[w X Y]_{T j}$} & $\cdots[w X Y]_{T q}$ & $b$ & & {$[w X Y H]$} \\
\hline$\left[w X^{2} Y^{2}\right]$ & {$\left[w X Y^{3}\right] \quad\left[w Y^{4}\right]$} & {$\left[w X Y^{2}\right]$} & {$\left[w Y^{3}\right]$} & {$\left[w Y^{2}\right]$} & {$\left[w Y^{2}\right]_{T 1}$} & ... & {$\left[w Y^{2}\right]_{T_{j}}$} & $\cdots \quad\left[w Y^{2}\right]_{T q}$ & $c$ & & {$\left[w Y^{2} H\right]$} \\
\hline$\left[w X^{3}\right]$ & {$\left[w X^{2} Y\right] \quad\left[w X Y^{2}\right]$} & {$\left[w X^{2}\right]$} & {$[w X Y]$} & {$[w X]$} & {$[w X]_{T 1}$} & $\ldots$ & {$[w X]_{r_{j}}$} & $\cdots \quad[w X]_{T q}$ & $d$ & & {$[w X H]$} \\
\hline$\left[w X^{2} Y\right]$ & {$\left[w X Y^{2}\right] \quad\left[w Y^{3}\right]$} & {$[w X Y]$} & {$\left[w Y^{2}\right]$} & {$[w Y]$} & {$[w Y]_{T 1}$} & $\ldots$ & {$[w Y]_{T_{j}}$} & $\cdots \quad[w Y]_{T q}$ & $e$ & & {$[w Y H]$} \\
\hline$\left[w X^{2}\right]$ & {$[w X Y] \quad\left[w Y^{2}\right]$} & {$[w X]$} & {$[w Y]$} & {$[w]$} & {$[w]_{T 1}$} & $\ldots$ & {$[w]_{T j}$} & $\cdots \quad[w]_{T q}$ & $f$ & $=$ & {$[w H]$} \\
\hline$\left[w X^{2}\right]_{T 1}$ & {$[w X Y]_{T 1}\left[w Y^{2}\right]_{T 1}$} & {$[w X]_{T 1}$} & {$[w Y]_{T 1}$} & {$[w]_{T 1}$} & {$[w]_{T_{1}}$} & $\ldots$ & 0 & $\begin{array}{ll}\cdots & 0\end{array}$ & $D_{1}$ & & {$[w H]_{T 1}$} \\
\hline$\cdots$ & $\ldots$ & $\cdots$ & $\ldots$ & $\ldots$ & $\ldots$ & $\cdots$ & $\ldots$ & $\ldots$ & $\ldots$ & & $\ldots \ldots$ \\
\hline$\left[w X^{2}\right]_{T j}$ & {$[w X Y]_{T_{j}}\left[w Y^{2}\right]_{T_{j}}$} & {$[w X]_{T j}$} & {$[w Y]_{T j}$} & {$[w]_{T j}$} & 0 & $\cdots$ & {$[w]_{T j}$} & 0 & $D_{j}$ & & {$[w H]_{T j}$} \\
\hline$\cdots$ & $\cdots$ & $\cdots$ & $\cdots$ & $\ldots$ & $\ldots$ & $\cdots$ & $\ldots$ & $\ldots$ & $\ldots$ & & $\ldots \ldots$ \\
\hline$\left[w X^{2}\right]_{T q}$ & {$[w X Y]_{T q}\left[w Y^{2}\right]_{T q}$} & {$[w X]_{T q}$} & {$[w Y]_{T q}$} & {$[w]_{T q}$} & 0 & $\cdots$ & 0 & $\cdots \quad[w]_{T q}$ & $D_{q}$ & & {$[w H]_{T q}$} \\
\hline
\end{tabular}

この式の各要素はつぎのように与えられる:

$\left[w X^{4}\right]=\left[w_{B i} X_{B i}{ }^{4}\right]_{i=1}^{p}+\left[w_{T j}\left[X_{T j t}{ }^{4}\right]_{t=1}{ }^{u}\right]_{j=1}{ }^{q}+\left[w_{S k} X_{S k}{ }^{4}\right]_{k=1}{ }^{r}$
$\left[w X^{3} Y\right]=\left[w_{B i} X_{B i}{ }^{3} Y_{B i}\right]_{i=1}^{p}+\left[w_{T j}\left[X_{T j t}{ }^{3} Y_{T j t}\right]_{t=1}{ }^{u}\right]_{j=1}{ }^{q}+\left[w_{S k} X_{S k}{ }^{3} Y_{S k}\right]_{k=1}{ }^{r}$
$\left[w X^{2} H\right]=\left[w_{B i} X_{B i}{ }^{2} H_{B i}\right]_{i=1}^{p}+\left[w_{T j}\left[X_{T j t}{ }^{2} H_{T j t}\right]_{t=1}{ }^{u}\right]_{j=1}{ }^{q}+\left[w_{S k} X_{S k}{ }^{2} H_{S k}\right]_{k=1}{ }^{r}$
$[w]=\left[w_{B i}\right]_{i=1}^{p}+\left[\left[w_{T j}\right]_{t=1}{ }^{u}\right]_{j=1}{ }^{q}+\left[w_{S k}\right]_{k=1}{ }^{r}$
$[w X Y]_{T j}=w_{T j}\left[X_{T j t} Y_{T j t}\right]_{t=1}{ }^{u}$
$[w]_{T j}=\left[w_{T j}\right]_{t=1}{ }^{u}$

ここに［］は境界点, 変位追跡点, 探査点に関するす べての座標データを用いて［］の中に示された量を計 算して集計することを, [ $]_{T 1},[]_{T j},[]_{T q}$ は個々の変 位追跡点 $(1),(j),(q)$ のみについてその点で観測された すべての時点の座標データを用いて［］の中の量を計 算して集計することを意味する。

このような手法で最小二乗法を適用すると, 正規方程 式(10)の左辺の正方行列は従来の解法1)で見られたような 特異行列にはならない。よってその逆マトリクスを両辺 に乗ずれば，末知量べクトル $\{a, b, c, d, e, f$, $\left.D_{1}, \cdots, D_{j}, \cdots \cdots, D_{q}\right\}$ の值を定めることができる。要 するに本研究では変位追跡点以外の諸点（地すべり境界 点・探查点）の座標データを最小二乗法に取り込んで同 時に処理することによって特異行列を避けることができ た。これにより研究目的 $(1-\mathrm{a})$ は解決された。

なお実際の計算にあたっては式(10)の正方マトリクスを 作成するかわりに，式(5)，(6)，(7)で与えられる境界点,
変位追跡点，探査点等の残差を上記の未知量ベクトルと の内積で表わす。いま未知量べクトルを:

$$
\begin{aligned}
{[X]=} & \left\{a, b, c, d, e, f, D_{1}, \cdots, D_{j}, \cdots \cdots, D_{q}\right\} \\
& (\{\quad\} \text { は列ベクトル記号 }) \quad \cdots \cdots \cdots \cdots \cdots .(12)
\end{aligned}
$$

と置くとき, たとえば変位追跡点 $(j)$ において時点 $(t)$ の 座標 $\left(X_{T j t}, Y_{T j t}, H_{T j t}\right)$ が得られた場合, 残差 $V_{T j t}$ をつ ぎの形で表わす。\{ $\}^{T}$ は列べクトルの転置すなわち行べ クトルを表わす。

$$
\begin{aligned}
& V_{T j t}=\left\{X_{T j t}{ }^{2}, X_{T j t} Y_{T j t}, Y_{T j t}{ }^{2}, X_{T j t}, Y_{T_{j t}}, 1,\right. \\
& 0, \cdots, 1, \cdots, 0\}^{T} \cdot\{a, b, c, d, e, f, \\
& \left.D_{1}, \cdots, D_{j}, \cdots, D_{q}\right\}-H_{T j t} \\
& =\left[U_{T j t}\right] \cdot[X]-H_{T j t}
\end{aligned}
$$

境界点, 変位追跡点, 探査点のすべての座標データに関 する残差べクトルを $[V]$ とすれば:

$$
\begin{aligned}
& {[V]=\left\{\left[U_{B 1}\right], \cdots,\left[U_{T j t}\right], \cdots,\left[U_{s r}\right]\right\} \cdot[X]-} \\
& \left\{H_{B 1}, \cdots, H_{T j t}, \cdots, H_{S r}\right\} \\
& =[U] \cdot[X]-[H]
\end{aligned}
$$


式(14)のマトリクス $[U],[X],[H]$ を用いると，正規方程 式(10)はつぎの演算で作成できる:

$$
[U]^{T} \cdot[W] \cdot([U][X]-[H])=0
$$

ここに $[W]$ は各点の座標データの重みを要素とする対 角行列で，次式で与えられる：

$$
[W]=\left[w_{B 1}, \cdots, w_{T j}, \cdots, w_{s r}\right]^{D}
$$

$$
\text { ([ ] }]^{D} \text { は対角行列) }
$$

式(15)より $[X]$ はつぎのように求められる。

$$
[X]=\left[[U]^{T}[W][U]\right]^{-1} \cdot\left[[U]^{T}[W][H]\right] \cdots \cdots(17)
$$

なお，式(14)で与えられる残差べクトルに関する左右両 辺の要素は, デー夕点の番号および時点において各行ご とに対応していなければならない。この条件さえ満足し ていれば，行の配列順序に関係なく式(17)で得られる解は 式(10)の解と一致する。よって式(14)を作成する段階で，境 界点や探査点のデー夕は自由に取捨選択できる。また 個々の変位追跡点についても各観測時点のデータを任意 に選択して解析に用いることができる。このようにして 研究目的 $(1-b)$ を解決できる。

\section{3 解析データの誤差と重み}

本研究の解析に用いるデー夕は，地すべり地における 境界点, 変位追跡点, 探査点などの三次元座標值である。 これらは測量または図上計測によって得られるものであ るため，観測や計測による誤差を伴う。

図上計測の場合，市販されている地形図上の諸点の位 置の誤差は $(0.4 \sim 1 \mathrm{~mm}) \times$ (縮尺分母), 標高の誤差は 等高線間隔の $1 / 2$ 程度である ${ }^{2)}$ 。しかし, 地形図上の等高 線に準拠して地すべり境界点や探查点の位置を定め，そ こから各点の座標デー夕を読み取る場合の誤差はかなり 大きくなる。等高線誤差に関する理論式は:

$($ 平面位置の誤差 $)=d L \pm d H \cdot \cot \theta$

(標高の誤差 $)=d H \pm d L \cdot \tan \theta$ $\cdot(18)$ で与えられる ${ }^{3)} 。 d L$ は平面位置の, $d H$ は標高の測定に介 入する誤差, $\theta$ は斜面の傾斜角である。地形図は通常, 写 真測量で作成される。西村 ${ }^{2)}$ はこの場合の数值を $d H=3$ $\mathrm{m}, d L=7 \mathrm{~m}$ としている。いま地すべり斜面の代表的な 傾斜角 ${ }^{4)}$ として $\theta=20^{\circ}, 25^{\circ}, 30^{\circ}$ を上式に代入して誤差の 最大值を計算してみると，つぎのようになる:

$\theta=20^{\circ}$ : (位置 $15 \mathrm{~m}$, 高さ $5.5 \mathrm{~m}$ )

$\theta=25^{\circ}:($ 位置 $13 \mathrm{~m}$, 高さ $6.3 \mathrm{~m}$ )

$\theta=30^{\circ}$ : (位置 $12 \mathrm{~m}$, 高さ $7.0 \mathrm{~m}$ )

さらにまた，地すべり境界とみなし得る諸点の位置を 現地で判定する際に生ずる誤差は, 亀裂や段差などの発 生形態によってかなりの幅を有する。よってその位置を 地形図上に示して計測する場合の誤差は，上記の等高線 の誤差および現地で確認される地すべり境界点の判定の 際に生ずる誤差の両者を考虑して推定すべきものである。 本研究では, $d S$ をひとつの地すべり境界点の平面位置の
誤差, $\theta$ をその点の周辺の平均傾斜角として,図上計測の 際に生ずる地すべり境界点の三次元的な位置誤差 $\Delta$ を 次式で定義する:

$$
\Delta=d S \cdot \sec \theta
$$

これに対して測量で諸点の座標を求める場合の誤差は, 地上測量方式では $5 \mathrm{~cm}$ 以内, 空中写真測量方式では 50 $\mathrm{cm}$ 以内と見積もることができる5,66。

変位追跡点の移動軌跡は, 2.1 の仮定が成り立つもの とすれば，空間においてほほ一直線を描くことになる。 しかし実際の軌跡には若干のばらつきが生ずる。その原 因を当該点の周辺の局部的な変形や測量誤差によるもの と考えて, 変位追跡点 $(j)$ の座標デー夕に含まれる総合的 な誤差を次の手順で求める:

(1)変位追跡点 $(j)$ の移動軌跡を直線で近似し, 最小二乗法 で直線の方程式を求める。この直線の初期の位置を $(X$, $Y, H)_{j 0}$, 方向余弦を $\left(C_{X}, C_{Y}, C_{H}\right)$ として, $(j)$ 点の 三次元移動べクトルを次式であらわす:

$$
\begin{aligned}
\left(X-X_{j 0}\right) / C_{X} & =\left(Y-Y_{j 0}\right) / C_{Y} \\
& =\left(H-H_{j 0}\right) / C_{H} .
\end{aligned}
$$

(2)この点の時点 $(t)$ における位置 $(X, Y, H)_{j t}$ から上式 の直線までの距離（残差）を $r_{j t}$ とすれば: ${ }^{7)}$

$$
\begin{aligned}
r_{j t} & =\left[\left(X_{j t}-X_{j 0}\right)^{2}+\left(Y_{j t}-Y_{j 0}\right)^{2}+\left(H_{j t}-H_{j 0}\right)^{2}\right. \\
& -\left\{C_{X}\left(X_{j t}-X_{j 0}\right)+C_{Y}\left(Y_{j t}-Y_{j 0}\right)+C_{H}\left(H_{j t}\right.\right. \\
& \left.\left.\left.-H_{j 0}\right)\right\}^{2}\right]^{1 / 2} \ldots \ldots \ldots \ldots \ldots \ldots \ldots \ldots \ldots \ldots \ldots \ldots \ldots \ldots \ldots \ldots \ldots \ldots \ldots \ldots \ldots \ldots \ldots \ldots \ldots \ldots \ldots \ldots \ldots \ldots \ldots \ldots \ldots \ldots \ldots \ldots
\end{aligned}
$$

(3)この変位追跡点の位置が $(u)$ 個の時点の観測で得られ ているとき，総合誤差 $r_{j}$ を次式であらわす：

$$
r_{j}=\left\{\sum r_{j t}{ }^{2} / u\right\}^{1 / 2} .
$$

一般に，地すべり境界点の座標は測量でも図上計測で も求め得るが, 変位追跡点の各時点の座標は測量でなけ れば求め得ない。よってすべての点のデータは測量方式 で求めて精度を統一することが理想的であり, 図上計測 はやむを得ない場合に限られる。境界点と変位追跡点の データの精度が異なる場合は, 式(8)に示した重み付きの 最小二乗法を適用する。この場合の重みは座標データの 誤差の二乗に反比例するものとして扱う ${ }^{3)}$ 。いま, 変位追 跡点 T $1, \mathrm{~T} 2, \cdots$ の誤差を $r_{T 1}, r_{T 2}, \cdots$, 重みを $w_{T 1}$, $w_{T 2}, \cdots$, 境界点 B $1, \mathrm{~B} 2, \cdots$ の誤差を $\Delta_{B 1}, \Delta_{B 2}, \cdots$, 重 みを $w_{B 1}, w_{B 2}, \cdots$ とするとき, 次式によって各デー夕の 重みを定める:

$$
\begin{aligned}
& w_{T 1}: w_{T 2}: \cdots: w_{B 1}: w_{B 2}: \cdots=1 / r_{T 1}{ }^{2}: 1 / r_{T 2}{ }^{2}: \cdots: 1 / \\
& {\Delta_{B 1}}^{2}: 1 / \Delta_{B 2}{ }^{2}: \cdots \cdots \cdots \cdots \cdots \cdots \cdots \cdots \cdots \cdots \cdots \cdots \cdots \cdots \cdots \cdots(23)
\end{aligned}
$$

以上の手順により, 変位追跡点および境界点のデータ に含まれる誤差の影響を解析に導入できる。すなわち研 究目的 $(1-\mathrm{c})$ を解決することができる。 


\section{3. シミュレーションによる検討 ${ }^{8)}$}

\section{1 解析上の鳍条件}

上記の手法によるすべり曲面の推定の精度が, 変位追 跡点や地すべり境界点の選定法およびそれらの座標デー 夕に含まれる誤差によってどのような影響を受けるかを シミュレーションによって検討する。正しいすべり曲面 (基準曲面) は次のような二次曲面方程式で与えられるも のとする:

$$
\begin{aligned}
& H=0.002 X^{2}+0.0005 X Y+0.003 Y^{2}-2.25 X \\
& +3.25 Y+1800
\end{aligned}
$$

この式で想定した地すべりの規模は，平面的な広がり が $500 \mathrm{~m} \times 500 \mathrm{~m}$ 程度のもので，すべり曲面と地表面と の交線上に図-1に示すように地すべり境界点 B 1〜B 13 を配置する。頭部境界点と脚部境界点との最 大距離を約 $450 \mathrm{~m}$, 左右の側部境界点間の最大距離を約 $370 \mathrm{~m}$ とし, 解析用の座標データを下記のように与える。 [境界点]各境界点ごとに, その点の位置決定に関する誤 差の最大值 $\left(E_{B}\right)$ を設定した上で, 測量または図上計測 で得られた個々の三次元座標值に次式で計算される誤差 $\delta$ を加える:

$$
\begin{aligned}
& \delta=E(2 R-1) \quad\left(E=E_{B} \text { or } E_{T}=\right.\text { 座標誤差の最大 } \\
& \text { 值 } R=0 \sim 1 \text { の乱数) }
\end{aligned}
$$

[変位追跡点] 移動ベクトルの起点として, 図-1の上で 正方格子の区画線 (50 m 間隔) の交点を任意に選ぶ。そ の点のすべり面の標高を式(24)で計算し, これにその点に おけるすべり面の深さ $D_{j}$ (各点ごとに一定值を任意に設 定できる）を加えたものを起点の標高とする。平面図上 における変位追跡点の全移動量は $100 \mathrm{~cm} \pm 30 \mathrm{~cm}$ の範 囲で与える。移動方向は平面図上でひとつの基準方向角 $A$ を設定し, その方向から次式で与えられる量 $(d A)$ だ け個々の変位追跡点の移動方向に変化を持たせる。

$$
\begin{aligned}
& d A=\tan ^{-1}\{1 /[10+3(2 R-1)]\} \\
& \quad=\tan ^{-1}\{1 /(7+6 R)\}(R=0 \sim 1 \text { の乱数 }) \quad \cdots \cdots(26)
\end{aligned}
$$
クトルの起点から終点まで等間隔にとった 11 個の点の $X Y$ 座標を式(23)に代入し，これに上記の深さ $D_{j}$ を加え て, 地下の曲面と平行に移動する変位追跡点の基礎デー 夕 $(X, Y, H)_{o j t}$ を作成する。そして解析に用いる変位 追跡点の座標データ $(X, Y, H)_{T j t}$ は, この基礎デー夕 $(X, Y, H)_{o j t}$ に式(25)で与えられる座標誤差 $\delta$ を加えたも のとして作成する。この場合, 式(25)の $E$ には変位追跡点 の座標決定において生ずる最大誤差 $\left(E_{T}\right)$ を用いる。

\section{2 境界点の選定と境界点データの誤差に関する検討}

解析に用いる境界点の選定場所と選定数，およびその 点の座標誤差が解析結果に与える影響を検討する。この 検討に用いる変位追跡点はすべての計算を通じて一定

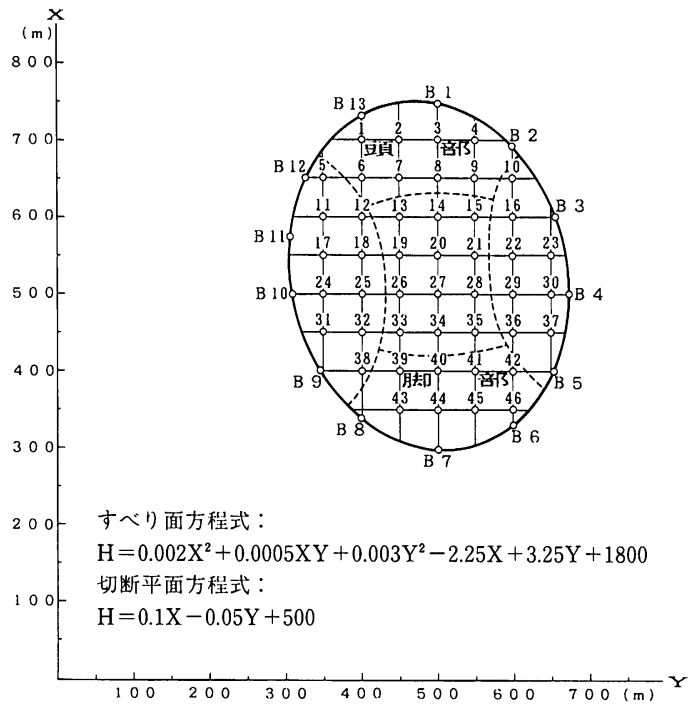

図ー1シミュレーションにおける変位追跡点と境界点の配置

(頭部: No. 3, 中部: No. 20, 右側部: No. 22, 左側部: No. 24, 脚部: No. 41, 計 5 点）とした。変位追跡点の 座標値に生ずる最大誤差 $E_{T}$ はいずれも $5 \mathrm{~cm}$ とした。

解析結果に対する信頼度は, 基準曲面（式(24)で与えら れる二次曲面）と推定曲面（境界点および変位追跡点の データを用いて式(10)を解いて得られる曲面）との標高の 差によって評価する。この場合, 次の量を定義する:

境界点標高整合誤差 $\left(e_{H}\right)=$ (解析で得られた境界点 の標高 $)$ - (基準曲面上の境界点の標高) ……....(27) すべり面深度整合誤差 $\left(e_{D}\right)=($ 変位追跡点で設定し た深度 $\left.D_{j}\right)$ - (解析で得られたすべり面の深さ) ‥(28) $e_{H}, e_{D}$ ともに正の場合は, 解析で得られた推定すべり面 のほうが正しいすべり面（基準曲面）よりも浅くなり， 負の場合は深くなる。

本節での検討は，境界点の位置設定に関する最大誤差 $E_{B}$ を $1 \mathrm{~m}, 5 \mathrm{~m}, 10 \mathrm{~m}, 50 \mathrm{~m}$ とした各場合について, 解 析に用いる境界点を 1 点から 13 点に至るまで 1 点ずつ, 地すべり地の周辺に一様に分布するように増加させて推 定曲面を求め, 上記の $e_{H}, e_{D}$ を調べた。変位追跡点, 境 界点とも 3.1 節の手法でデータに誤差を与えたのち, 2.3 節の手法で各データに重みを持たせた。解析結果の数值 等は紙面の都合上省略し，考察を以下に要約する。 $N$ は 解析に用いた境界点の数, $E_{B}$ は境界点の位置設定に関す る最大誤差である。

$[\mathrm{C} 1] N \leqq 2 て ゙ は ， E_{B}$ が小さくても， $e_{D}$ が極端に大きく なる場合が多い。しかし $N \geqq 3 に な る と e_{D}$ は顕著に減少 する。よって解析に用いる境界点は 3 点以上とすること が望ましい。

[C 2] すべての境界点に対して $E_{B}=1 \mathrm{~m}$ とすると, 得ら れる解は非常に安定する。 $N \geqq 4$ では $e_{H}$ も $e_{D}$ も $1 \mathrm{~m}$ 以 
下となった。しかし全点で $E_{B}=1 \mathrm{~m}$ という条件を実際 の地すべり地で得ることはかなり困難である。

[C 3]すべての境界点に対して $E_{B}=5 \mathrm{~m}$ とした場合に は, $N \geqq 5$ で $e_{H}<6 \mathrm{~m}, N \geqq 6 て ゙ e_{D}<4 \mathrm{~m}$ とすることが できた。そしてすべての境界点に対して $E_{B}=10 \mathrm{~m}$ とし た場合には, $e_{H}$ と $e_{D}$ を $10 \mathrm{~m}$ 以下に保持するためには $N$ $\geqq 6 か ゙$ 必要となった。このように境界点の位置設定誤差 $E_{B}$ の増大とともに推定の精度は低下し,推定の誤差を一 定值以下に保つために必要な境界点の数は増加する。

[C 4] すべての境界点に対して $E_{B}=50 \mathrm{~m}$ という非常に 大きい誤差を与えた場合には， $e_{H}<45 \mathrm{~m}$ を保持するた めには $N \geqq 7, e_{D}<30 \mathrm{~m}$ を保持するためには $N \geqq 8$ を 必要とした。これは実際の現象と極めてかけ離れた不合 理なものである。すなわち，解析に用いるすべての地す ベり境界点の位置設定誤差が地すべりの平面的な広がり (最大長) の $1 / 10$ 以上にも達するような場合には本法を 適用すべきでない。

$[\mathrm{C} 5] E_{B} \leqq 5 \mathrm{~m}$ の場合は $N$ を増加させると $e_{H}, e_{D}$ ともに 減少する傾向が見られたが， $E_{B} \geqq 10 \mathrm{~m}$ になるとそのよ うな傾向は見られない。

\section{3 境界点データの重みに関する検討}

解析に用いる変位追跡点とその座標誤差は前節と同一 とした上で, 境界点デー夕の重みに差をつけた。境界点 は 9 点選定し, 各点ごとに位置設定の最大誤差 $\left(E_{B}\right)$ に $5 \sim 100 \mathrm{~m}$ の範囲で種々の数值を与えた。この数值は第 4 章で扱う小諸地すべりのデータにほほ対応させた。シ ミュレーションに関する考察を以下に示す。

[C 6] 境界点データの重みの大きい点では $e_{H}$ は小さく, 重みの小さい点では $e_{H}$ は大きくなる。

[C 7]重みの比較的大きい(変位追跡点の重みの最大値を 1 としたとき $10^{-5}$ 程度）境界点を 3 点与えておけば，そ れよりも重みの小さい $\left(10^{-7}\right.$ 以下) 境界点をかなり解析 に追加しても $e_{D}$ には大差を生じない。これより, 解析に 当たっては精度の高い境界点を 3 点以上地すべり地を取 り囲むように配置することが推定の精度を高めるうえで 大切なポイントと言える。

[C 8] 試みにすべての変位追跡点と境界点の重みを 1 と して解析すると, $N$ の増加とともに $e_{D}$ は極度に増加し, $e_{H}$ は 0 に近付く。つまり推定曲面が極度に浅くなる一 方, 境界点での整合性は向上する。しかしこれはすべり 面推定とは言えない。よってすべり面推定ではデー夕の 重みが重要な役割をなすことがわかる。

\section{4 变位追跡点の配置に関する検討}

境界点は B 1, B 3, B 6, B 9, B 12 の 5 点に固定し, 全点とも位置設定の最大誤差 $E_{B}$ を $5 \mathrm{~m}$ としてデータの 重みを考慮する。この条件の下で 5 個の変位追跡点（座 標值最大誤差 $E_{T}=5 \mathrm{~cm}$ ） の配置場所を変化させた。
[C 9] 变位追跡点を地すべり地の全域に一様に配置する と解の精度が高くなる。これは 3.2 節で述べたような配 置である。5 個の変位追跡点を地すべり地の上半部また は下半部に偏して配置すると $e_{D} か ゙ 50 \%$ 程度増加する。 中央部に集中的に配置すると $e_{D}$ は約 2 倍となる。 $e_{H}$ に ついては顕著な変化は見られない。

\section{5 変位追跡点の設定数と座標データの誤差に関する 検討}

境界点の配置と位置設定の最大誤差は前節と同一とす る。変位追跡点は 1 点から 10 点に至るまで, 地すべり地 域内になるべく一様に分布するように 1 点ずつ増加させ た。そして変位追跡点の座標值の最大誤差 $E_{T}$ を 5,10 , $20 \mathrm{~cm}$ とした場合について検討した。考察を以下に示す。 [C 10] 解析に用いる変位追跡点の数を 2 点以上とする と, $e_{H}$ は-7〜 $+5 \mathrm{~m}$ の範囲におさまった。変位追跡点の 座標データの精度が低下すると, 境界点のデータの重み が相対的に増すために， $e_{H}$ が若干 (20\%程度) 減少する 傾向が見られる。

[C 11] 解析に用いる変位追跡点の数が $3 \sim 4$ 点以上にな ると, 変位追跡点データの誤差 $\left(E_{T}\right)$ の大きさに関係な く各変位追跡点のすべり面の深さは 1 1 2 $\mathrm{m}$ 以下の変 動で一定值に収束する。しかしそれらは必ずしも正しい 深さを与えるものではない。すべり面深度の整合誤差 $\left(e_{D}\right)$ は $E_{T}$ と共に増大する $\left(E_{T}=5,10,20 \mathrm{~cm}\right.$ に対し $\tau e_{D}=(1 \sim 5), \quad(1 \sim 8), \quad(3 \sim 19) \mathrm{m}$, 誤差率 $\left(e_{D} / D\right)$ は $(0.01 \sim 0.1),(0.02 \sim 0.15),(0.1 \sim 0.25)$ となる $)$ 。な お変位追跡点の数を 1 2 点とした場合の推定曲面は極 めて浅く, 変位追跡点を用いない (0 点) 場合には上に凸 の推定曲面となった。このように解析に用いる変位追跡 点の数とデータの精度は重要である。すべり面推定解析 においては, 変位追跡点は 3 点以上, デー夕の誤差は 10 cm 以下とすることが必要である。

\section{4. 実際の地すべり地への適用例と考察}

この解析手法を, 図一 2 に示すような小諸市南部の千 曲川の攻撃斜面に発生した地すべりに適用してみる。地 すべりの詳細については本誌 (Vol. 23-4, Vol. 26-3) で 述べているので省略する1)5)。

\section{1 解析用データと精度}

変位追跡点 (図-2 の○は移動, Đは微動, は不動点) の三次元座標は 1 力間隔の 8 回の観測 (1983.41983.11)で得られている。これはトータルステーション 方式の観測によるもので, 座標決定で生ずる最大誤差は $5 \mathrm{~cm}$ 以内と考えられるが, 以下の解析ではさらに誤差の 幅を見込んで, $E_{T}=10 \mathrm{~cm}$ とした。この観測期間におけ る各測点の三次元移動量は $17 \sim 32 \mathrm{~cm}$ であった。水準測 量 (図一-2の口は上昇, 円は微動, 口は不動) は単に, 地 


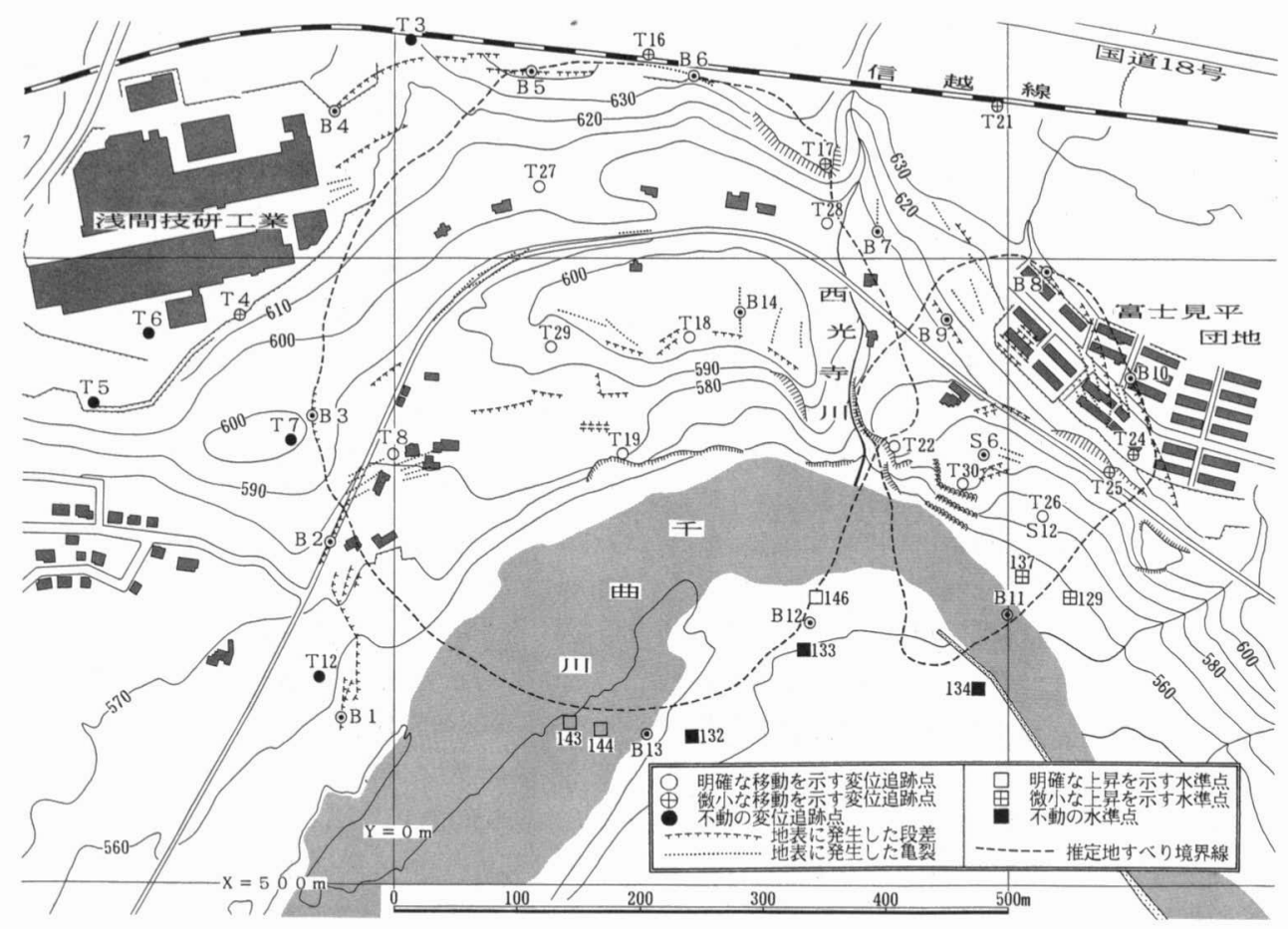

図ー2 小諸地すべり地における地表の変状・変位追跡点・境界点・探查点・推定地すべり影響圏

すべりの脚部の位置の探索を目的としたもので, 観測 データは解析に直接用いるものではない。

図一2には現地に発生した段差や龟裂を記入した。 B 1，B 2，，B 14 はそれらの位置で推定した地すべり 境界点である。但し B 11, B 12, B 13 の 3 点について は，上昇を示す水準点とそれに最寄りの不動の水準点と の中点を境界点として推定した。地すべり境界点の設定 に関する最大誤差 $E_{B}$ は, 式(19) と現地の変状の発生状況 とを考慮して, 境界点の番号順（B 1, B 2, B 3, ․, $\mathrm{B} 12, \mathrm{~B} 13, \mathrm{~B} 14)$ ： $100 \mathrm{~m}, 21,10,80,5,5$, $54,11,12,10,50,30,40,51 \mathrm{~m}$ の数值を与えた。

\section{2 西光寺川右岸の地すべりに関する検討*}

表 -1 は, 図 -2 の西光寺川右岸の変位追跡点と境界点 のデータを用いた解析結果である。解析系番号 R 1 から R 8 までは常に 5 個の変位追跡点（T 18, T 19, T 27, T 28, T 29）を用い，これに9個の地すべり境界点 (B 1, B 2, B 3, B 4, B 5, B 6, B 7, B 12, B 13) の 中から解析用のデータ点を 1 点ずつ増やしてすべり面推 定を行ったもの,解析番号 R 9 から R 16 まではこれに変 位追跡点（T 8) を追加して同様の解析を行なったもので ある。この表において (境界点標高整合誤差) $=$ (推定し

* 地すぺりによる地表の変状は, 千曲川に合流する西光寺川の両岸 に発生している。文献 1 (1989) では, 右岸と左岸の地すべりは それぞれ独立した移動ブロックと考えられることを示した。よっ て本文でも西光寺川をはさむ両岸の地すべりを別個に扱う。
たすべり面の境界点位置での標高 $)$ - (境界点データの標 高）である。数值のない（・）の記号は, その境界点の データを解析に用いなかったことを意味する。すべり面 深度は解析に用いた変位追跡点から地下の推定すべり面 までの深さである。ただし［］内の数值は, 解析に用 いなかった変位追跡点の位置で, 推定すべり面までの深 さを計算したものである。表中の数值の単位はすべて (m)である。なおこの表には境界点と変位追跡点の各 データの重みを併記した。

実際の地すべり地では前章のシミュレーションとは異 なり,すべり曲面の形状は未知である。従って何を規範 として最確值を判定するかが問題となる。本文では判定 の規範としてつぎの 2 点に着目した:

a ）各変位追跡点における推定すべり面の深さが一定值 に収束すること。

b ）境界点及び探查点における標高の整合誤差が 0 に近 くなること。

この規範に基づいて, 西光寺川右岸のすべり面の推定 に関する考察を以下に要約する。

[C 12] 各変位追跡点の推定すべり面の深度は, 解析系番 号 R 11 から R 15 までは 1 2 m の差で一致している。 またこれらの解析結果における境界点標高整合誤差は デー夕精度の高い B 5, B 6, B 3 等では $3 \mathrm{~m}$ 以下であ る。よって R 11 から R 15 までの解のいずれかを用いて すべり面を推定できるものと判定する。R12によるすべ 
表-1 すべり面の推定解析結果（小諸市西光寺川右岸） [単位: $\mathrm{m}$ ]

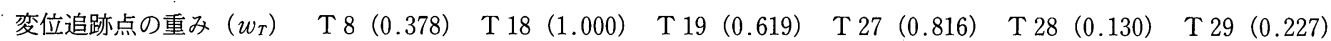

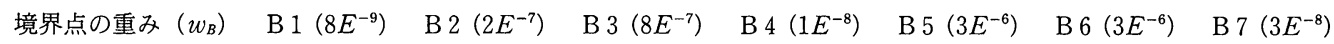

B $12\left(9 E^{-8}\right) \quad$ B $13\left(5 E^{-8}\right)$ \{記号: $\left.E^{-n}=\times 10^{-n}\right\}$

\begin{tabular}{|c|c|c|c|c|c|c|c|c|c|c|c|c|c|c|c|c|c|}
\hline \multicolumn{2}{|c|}{ 解析系番号 } & R 1 & R 2 & R 3 & R 4 & R 5 & R 6 & R 7 & R 8 & R 9 & R 10 & R 11 & R 12 & R 13 & R 14 & R 15 & R 16 \\
\hline \multirow{9}{*}{ 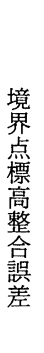 } & B 1 & • & • & • & • & • & 129 & 132 & 107 & • & • & • & - & - & 106 & 107 & 95 \\
\hline & B 2 & • & • & • & • & • & • & • & 28 & • & • & • & • & • & • & • & 22 \\
\hline & B 3 & • & 1 & 2 & 2 & 2 & 0 & -1 & -8 & • & 0 & 0 & 0 & 0 & -1 & -2 & -8 \\
\hline & B 4 & • & • & • & • & $\cdot$ & • & 76 & 82 & • & - & $\cdot$ & • & - & • & 87 & 86 \\
\hline & B 5 & -2 & -3 & -3 & -3 & -3 & -3 & -3 & -3 & -2 & -2 & -2 & -2 & -2 & -2 & -3 & -2 \\
\hline & B 6 & 2 & 2 & 3 & 3 & 3 & 3 & 3 & 2 & 2 & 2 & 2 & 2 & 2 & 2 & 2 & 2 \\
\hline & B 7 & • & • & • & • & 1 & 6 & 3 & 12 & $\cdot$ & • & • & - & 16 & 17 & 16 & 18 \\
\hline & B 12 & • & • & -17 & -19 & -19 & -13 & -16 & -3 & • & • & 3 & 1 & -1 & 1 & -1 & 5 \\
\hline & B 13 & • & $\cdot$ & • & 23 & 23 & 21 & 22 & 18 & - & - & - & 18 & 18 & 17 & 17 & 16 \\
\hline \multirow{6}{*}{$\begin{array}{l}\text { す } \\
\text { ベ } \\
\text { り } \\
\text { 面 } \\
\text { 梁 } \\
\text { 度 }\end{array}$} & T 8 & {$[-19]$} & {$[26]$} & {$[43]$} & {$[43]$} & [43] & {$[45]$} & {$[45]$} & [53] & 44 & 49 & 48 & 49 & 48 & 49 & 49 & 54 \\
\hline & T 18 & 150 & 161 & 133 & 134 & 134 & 131 & 132 & 128 & 124 & 125 & 126 & 127 & 127 & 126 & 126 & 124 \\
\hline & Т 19 & 130 & 141 & 129 & 130 & 130 & 130 & 129 & 129 & 126 & 127 & 127 & 128 & 128 & 128 & 127 & 127 \\
\hline & Т 27 & 57 & 66 & 65 & 65 & 65 & 65 & 64 & 64 & 62 & 63 & 63 & 63 & 63 & 63 & 62 & 62 \\
\hline & T 28 & 59 & 83 & 23 & 22 & 23 & 19 & 21 & 14 & 6 & 7 & 10 & 10 & 12 & 11 & 11 & 10 \\
\hline & Т 29 & 109 & 124 & 124 & 124 & 124 & 124 & 123 & 124 & 121 & 123 & 123 & 123 & 123 & 123 & 122 & 123 \\
\hline
\end{tabular}

り曲面の方程式を次に示す。他の解析系番号による曲面 方程式もこれと大差はない。

$$
\begin{aligned}
H & =0.00195 X^{2}+0.000001 X Y+0.00227 Y^{2} \\
& -3.337 X-0.811 Y+1959 \ldots \ldots \ldots \ldots \ldots \ldots \ldots \ldots \ldots . . .
\end{aligned}
$$

参考までに, 文献 1 の解析手法で得られたこの領域に対 する推定すべり面の方程式をつぎに示す:

$$
\begin{aligned}
& H=0.00192 X^{2}+0.00024 X Y+0.00288 Y^{2} \\
& -3.345 X-1.058 Y+1965
\end{aligned}
$$

要するに前章の [C 7], [C 8], [C 9] で述べた考察が実 際の地すべり地に有効に適用できることが分かる。

[C 13] 境界点標高整合誤差はデー夕の重みが大なるもの ほど小さい。重みの小さい境界点を解析のデー夕に加え てもすべり面深度の数值には大きな変化は生じない。反 面, 重みの大きい境界点は解にかなりの影響を及ぼす(解 析系番号 R 8, R 16 参照)。

[C 14］変位追跡点 T 8 のデー夕を解析に用いるか否か で，この点から遠い位置にある T 18, T 28 のすべり面深 度には $10 \mathrm{~m}$ 前後の差が生じている。変位追跡点 $\mathrm{T} 8$ を 用いない場合の解から最確值を見出すことはむずかしい。 [C 15] T 8 のすべり面深度は, 解析系番号 R 8 では [53] m, R 16 では $54 \mathrm{~m}$ である。この点に注目して R 16 の諸 数値を最確值とみなすことも考えられる。上記の [C 12] と比較した場合, すべり面深度の最大較差は T 8 で $6 \mathrm{~m}$ となるが, 他の変位追跡点では $3 \mathrm{~m}$ 以下である。境界点 標高整合誤差には若干の変動が見られる。

\section{3 西光寺川左岸の地すべりに関する検討}

表 -2 は, 図-2に示す西光寺川の左岸を対象として,
変位追跡点と境界点および探査点 (ボーリング点)のデー 夕を用いた解析結果である。主な考察を以下に示す。な お図一 2 の探查点 S 12 は T 26 と同じ場所にある。 [C 16] 変位追跡点と境界点のデータのみを用いた解析 （解析系番号 L 13, L 14, L 15) では, 得られた解の数値 が安定せず，すべり面の推定ができない。これは解析に 用い得る 3 個の変位追跡点（T 22, T 26, T 30) が, 境 界点の配置に対してやや偏った場所に集中しているため と考えられる（図 -2 参照）。

[C 17] 変位追跡点と境界点のデータに探査点のデータ (ボーリングによるすべり面の三次元座標値)を加えるこ とにより, 得られる解の数值は安定してくる。特に S 12 の寄与が大きい。前記の規範ａ）を考慮した場合, 信頼 できる解はL 2 とL 7 またはL 3 と L 10 のいずれかに しぼられてくる。さらに前記の規範 b)を考慮すれば, L 2 または L 7 をもってすべり面を推定すべきことが分かる。 [C 18]解析系番号 L 16 は，4 個の境界点と 2 個の探查点 のみを用いてすべり曲面を推定し, 各変位追跡点のすべ り面深度を推定曲面から計算で求めたものである。L 11 の解にかなり近いものとなっている。

\section{4 平面図上における地すべり影響圈の推定}

図ー2に破線で示した図形は, 推定した地下すべり面 方程式による曲面と地表面との交わりである。破線で囲 まれた領域が地すべりの影響圈と推定される。すべり曲 面方程式は西光寺川右岸では式(29)すなわち R 12 による ものを,左岸については L 7 による次式を用いた。考察を 以下に要約する。 
表ー2 すべり面の推定解析結果（小諸市西光寺川左岸） [単位: $\mathrm{m}$ ]

\begin{tabular}{|c|c|c|c|c|c|c|c|c|c|c|c|c|c|c|c|c|c|}
\hline & \multicolumn{2}{|c|}{$\begin{array}{l}\text { 境界点の重み } \\
\text { 探査点の重み }\end{array}$} & $\begin{array}{l}\left(w_{B}\right) \\
\left(w_{S}\right)\end{array}$ & \multicolumn{2}{|c|}{$\begin{array}{l}\text { B 8 }\left(1 E^{-6}\right) \\
\text { S 6 }\end{array}$} & \multicolumn{2}{|c|}{$\begin{array}{cc}\text { B } 10 & \left(1 E^{-6}\right) \\
\text { S } 12 & \left(1 E^{-6}\right)\end{array}$} & \multicolumn{2}{|c|}{ B $11\left(5 E^{-8}\right)$} & \multicolumn{2}{|c|}{ B $12\left(1 E^{-7}\right)$} & & $4(5 E$ & $\begin{array}{l}-8 \text { ) } \\
\text { \{記号 }\end{array}$ & $: E^{-n}=$ & $=\times 10^{-}$ & \\
\hline \multicolumn{2}{|c|}{ 解析系番号 } & L 1 & L 2 & L 3 & L 4 & L 5 & L 6 & L 7 & L 8 & L 9 & L 10 & L 11 & L 12 & L 13 & L 14 & L 15 & L 16 \\
\hline \multirow{7}{*}{ 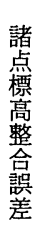 } & B 8 & 0 & 1 & 0 & 0 & 0 & 0 & 0 & 0 & 0 & 0 & 0 & 0 & 0 & 0 & 0 & 0 \\
\hline & B 10 & -2 & -1 & 0 & -1 & -2 & -2 & -1 & 0 & -1 & 0 & 0 & 0 & -1 & 0 & 0 & 0 \\
\hline & B 11 & -11 & -4 & -26 & -6 & -1 & -11 & -3 & -27 & -11 & -10 & 1 & -7 & 34 & 0 & 0 & 0 \\
\hline & B 12 & - & • & $\cdot$ & • & $\cdot$ & $\cdot$ & • & $\cdot$ & • & • & • & • & -11 & -4 & • & - \\
\hline & B 14 & - & - & • & • & • & - & - & - & • & • & • & • & 18 & 6 & 0 & 0 \\
\hline & S 6 & - & • & • & • & 2 & 0 & 0 & 0 & 2 & -1 & 0 & 0 & • & • & • & 0 \\
\hline & S 12 & 3 & 1 & 1 & 1 & - & 3 & 1 & 1 & 0 & 1 & 0 & 1 & - & $\cdot$ & $\cdot$ & 0 \\
\hline \multirow{3}{*}{$\begin{array}{l}\text { 面 } \\
\text { 梁 } \\
\text { 度 }\end{array}$} & Т 22 & 57 & 48 & 68 & {$[-61]$} & 96 & 58 & 45 & 80 & {$[12]$} & 56 & {$[54]$} & {$[2]$} & 18 & 30 & 38 & [59] \\
\hline & Т 26 & 22 & 24 & [24] & 24 & 8 & 22 & 24 & {$[24]$} & 25 & {$[24]$} & 24 & {$[24]$} & -28 & {$[-4]$} & {$[-4]$} & [24] \\
\hline & Т 30 & 63 & [59] & 63 & 35 & 66 & 63 & [58] & 67 & 60 & {$[61]$} & {$[54]$} & 63 & 7 & 26 & 31 & [54] \\
\hline
\end{tabular}

・は当該解析系において解析用のデータを採用しない境界点および探査点

[ ]の中の数值は解析に用いない変位追跡点のすべり面深度を推定曲面方程式で計算したもの

$$
\begin{aligned}
H & =0.00188 X^{2}-0.00037 X Y+0.00402 Y^{2} \\
& -2.790 X-3.492 Y+2456 \ldots \ldots \ldots \ldots \ldots \ldots \ldots \ldots
\end{aligned}
$$

[C 19]西光寺川右岸の地すべりの境界線は，解析に用い た境界点（B 3，B 5，B 6，B 12）の位置をかなり正確に 通過する。解析に用いない B 12 との整合性も良い。境界 点 B 13 や水準点 143,144 等との整合性はやや劣り，水 平位置にして $20 \mathrm{~m}$ 程度の較差がある。B 1 から B 2 にわ たって顕著な段差が発生しているが，推定した境界線は これと大きく離れている。この段差を主すべりの影響を 受けた副次的な破壊現象と考えれば一応の説明はできる。 B 4 から B 5 にわたる段差と推定境界線との不整合も副 次的な地すべりと考えられる。

[C 20]西光寺川左岸の地すべりの境界線は，地すべり地 頭部における地表の変状に対しては比較的良く対応して いる。脚部の手掛かりとなるものは水準点 129 と 137 が 微動していることのみであるため, その一帯の境界線の 信頼度は低い。しかし現地の変状と対比した場合，無理 のない形状である。

\section{5.おわりに}

本研究は, 地すべり地の地表の変位追跡測量データを 解析して，地下すべり面の三次元形状をひとつの曲面方 程式で近似して推定することを目的としたものである。 これまでの手法に改良を加え，これをシミュレーション および実際の地すべり地への適用によって検討した。解
析手法の改良によって, 滑落崖や脚部隆起点の位置の データおよびボーリング等で得られた地下すべり面の位 置のデー夕を解析に取り入れることができた。またこれ らのデータおよび測量データに対して, 精度に応じた重 みを付けて解析することにより，すべり面推定の精度を かなり向上させることができた。ただし実際のすべり面 の形状はひとつの連続曲面方程式で表現できるようなも のではない。今後はさらに複雑な曲面形状による推定法 の検討が必要である。

\section{参考文献}

1) 吉澤孝和: 地上測量による地下すべり面形状および地す ベり影響範囲の推定, 地すべり, Vol. 26, No. 3, pp. 28一 39, 1989.

2）西村蹊二: 地図の利用法，朝倉書店，pp. 56-63，1978。

3 ）吉澤孝和: 測量実務必携，オーム社，p. 30，p. 208, 1975 .

$4 ）$ 望月巧一: 長野県北部山地における浅層型地すべりの機 構と地形特性，地すべり，Vol. 20，No. 1, pp. 10-20, 1983.

5 ）吉澤・細川: 地すべり地における地表変位測量デー夕を 用いた円弧すべりの解析，地すべり，Vol. 23，No. 4, pp. $13-22,1987$.

6 ）吉澤・他: 空中写真測量による地すべり情報の提供とす ベり面の解析, 地すべり, Vol. 27, No. 4, pp. 9-17, 1991.

7 ) 泉・他: 共立 数学公式, 共立出版, p. 134, 1961 .

8）吉澤・宮澤: 地すべり地の測量による地下の三次元すべ り曲面の推定について, 日本自然災害学会講演要旨集, pp. $52-53,1991$.

（原稿受理日 平成 3 年 10 月 22 日） 
引張り菓裂を有する斜面の全体安全率の計算

「地すべり」Vol. 28,No. 4 (通算第 108 号) pp. 1 5, 1992 年（平成 4 年）3月

鵜飼 恵三

地下すべり面推定における三次元移動軌跡法の改良

「地すべり」Vol. 28, No. 4（通算第 108 号）pp. 6〜14, 1992 年（平成 4 年） 3 月

吉澤 和, 宮澤 圭

地すべり地の地表の変位追跡測量データを解析して, 地下すべり面の三次元形状をひとつの曲面方程式で近似

して推定する。これまでの手法に改良を加え, 滑落崖や脚部隆起点の位置のデータおよびボーリング等で得られ た地下すべり面の位置のデー夕を解析に取り入れた。これらのデータの精度に応じた重みを付けて解析すること

により，すべり面推定の精度をかなり向上させることができた。

岩手県南西部川尻・焼石岳地域の地すべり地形について

「地すべり」Vol. 28, No. 4 (通算第 108 号) pp. 15 22, 1992 年（平成 4 年） 3 月

多田 元彦, 大河原正文, 千田 成人

Kamaya Landslide at Kikonai Town, Southern Hokkaido, Japan

-A Landslide History in Terms of Geomorphologic and Forestation Change -

「地すべり」Vol. 28, No. 4 (通算第 108 号) pp. 23〜28, 1992 年（平成 4 年）3 月

Hiromitsu YAMAGISHI and Kazuo SHIMURA

空中写真により, 南部北海道の木古内町釜谷の丘陵性山地で, かなり大規模な地すべり (幅 $300 \mathrm{~m}$, 長さ $700 \mathrm{~m}$ ) が最近発生していたことがわかった。それ以前の空中写真の判読により，この地すべりは 1988 年の 6 月 23 日以 降, 7 月 27 日以前に起こったことが明らかになった。さらに, 1948 年頃, 1959 年, 1973 年, 1976 年, 1988 年に 撮影されたこの地すべり付近の空中写真を判読すると, 針葉樹林（杉の人工林）の伐採と関連した地すべり地形 の変化が読み取れる。さらに, 筆者らはこの地すべりの発生前と後とを比較して量的な解析を行い, 現地調査を も実施した。その結果, 地質的な素因としては, 緩傾斜の新第三紀泥岩層にはさまる粘土化した流紋岩質凝灰岩 から発生した流れ盤型であり, 誘因としては 6 月ー7月始めのやや強い降雨による, 古い地すべり面の間吵水圧の 上昇が推定される。

房総半島鹿野山周辺地域の斜面崩壊の地形・地質的特性

「地すべり」Vol. 28, No. 4 (通算第 108 号) pp. $29 \sim 36,1992$ 年（平成 4 年） 3 月

古谷 尊彦; 大倉 博 